\title{
Double Jeopardy's Dual Sovereignty: A Tragic (and Implausible) Lack of Humility
}

\author{
Stephen E. Henderson \& Dean A. Strang*
}

\begin{abstract}
The core proposition of the Fifth Amendment's Double Jeopardy Clause is as intuitive as it is straightforward. After all, if a state could prosecute someone despite her previous conviction or acquittal, then the scope of punishment would be unlimited and its threat unending-the sort of proposition only a tyrant could love. Yet, in Gamble v. United States, the Supreme Court once again blessed a dual sovereignty exception that permits just such duplicative prosecutions. We hardly are the first to question this rule, but we submit the Court's most recent primary mistakes were two. First, the Court began from a conception of constitutional community contrary to our Framers' own; and when one reaches for a grab bag of history, jurisprudence, and commentary, that starting point makes a difference. Second, the Court ignored both the logic of America's founding and recent double jeopardy jurisprudence, both of which strongly counsel against the exception in the federal-state context. We hope that a future Court will be more receptive to the nation's constitutional structure and to the genuine but limited needs of criminal justice.
\end{abstract}

* Stephen Henderson is the Judge Haskell A. Holloman Professor of Law at the University of Oklahoma; Dean Strang is a Distinguished Professor in Residence at Loyola University Chicago School of Law. Some of these arguments were first introduced in an amicus brief. See Brief of Amici Curiae Criminal Procedure Professors Stephen E. Henderson, George C. Thomas III, Michael J. Z. Mannheimer, and Kiel Brennan-Marquez In Support of Petitioner, Gamble v. United States, 139 S. Ct. 1960 (2019) (No. 17-646). In addition to those co-authors, we wish to thank Evelyn Aswad, Steven Gensler, Roger Michalski, Kelly Sorensen, Andrew Strauss, James Boyd White, and, for research assistance, Jacob Black. 
TABLE OF CONTENTS

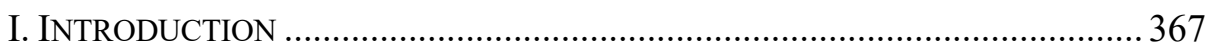

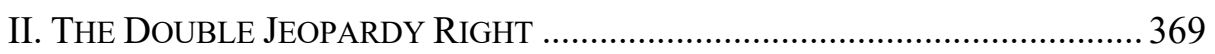

III. CONSTITUTIONAL TEXT, COMMUNITY, AND DUAL SOVEREIGNTY ......... 371

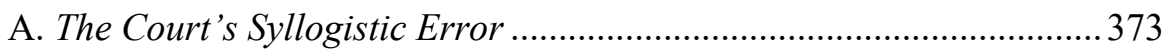

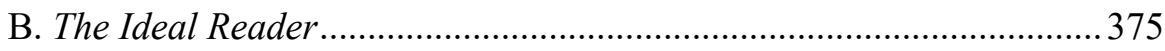

1. A People Humbled Before Government ............................................378

2. A Government Humbly Serving Its People ....................................... 381

IV. FEDERALISM, IGNORED PRECEDENT, AND DUAL SOVEREIGNTY ............. 383

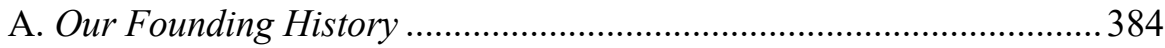

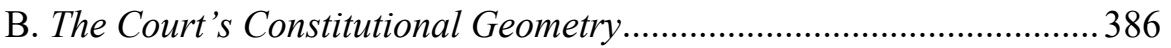

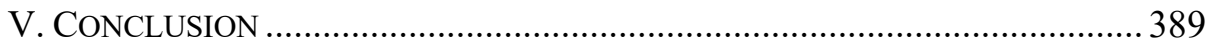




\section{INTRODUCTION}

Decades ago, Justice Hugo Black recognized that "double prosecutions for the same offense are . . contrary to the spirit of our free country." The proposition is hardly surprising, as duplicative prosecution was also contrary to the spirit of peoples in ancient Athens, in the Roman Republic and Empire, and in the Old Testament. ${ }^{2}$ Indeed, "[f]ear and abhorrence of governmental power to try people twice for the same conduct is one of the oldest ideas found in western civilization."

It is truly odd, then, that the United States Supreme Court continues to adhere to the rule-swallowing exception of dual sovereignty. According to the Court, the Fifth Amendment Double Jeopardy Clause protects against a duplicative prosecution only by the very same sovereign, and, even more striking, for these purposes the United States is considered a sovereign independent from its constituent states. ${ }^{4}$ So, after Alabama prosecuted, convicted, and punished Terance Gamble for possessing a firearm, the United States was free to - and did - prosecute, convict, and punish him for precisely the same thing. ${ }^{5}$ In America, then, "inescapably, a [person] is forced to face danger twice for the same conduct." 6

1 Bartkus v. Illinois, 359 U.S. 121, 150 (1959) (Black, J., dissenting). Justice Black was joined by Chief Justice Earl Warren and Justice William O. Douglas. Justice William J. Brennan Jr. also wrote a dissent in which he highlighted the rather amazing involvement of the federal government in the particular state prosecution. See id. at 169 (Brennan, J., dissenting) ("Not content with the federal jury's resolution of conflicting testimony in Bartkus' favor, the federal officers engineered this second prosecution and on the second try obtained the desired conviction."). Fascinatingly, there is even more to that story, but we leave its telling for another day.

2 See Gamble v. United States, 139 S. Ct. 1960, 1996 (2019) (Gorsuch, J., dissenting); Bartkus, 359 U.S. at 151-52 (Black, J., dissenting) (same).

3 Bartkus, 359 U.S. at 151 (Black, J., dissenting).

4 See Gamble, 139 S. Ct. at 1963-64. The Double Jeopardy Clause provides that "[n]o person shall be ... subject for the same offence to be twice put in jeopardy of life or limb," (U.S. CONST. amend. V), but the Court has "long held that a crime under one sovereign's laws is not "the same offence' as a crime under the laws of another sovereign." Gamble, 139 S. Ct. at 1964. "The Double Jeopardy Clause thus drops out of the picture when the entities that seek successively to prosecute a defendant for the same course of conduct are separate sovereigns." Puerto Rico v. Sanchez Valle, 136 S. Ct. 1863, 1870 (2016) (quotation marks omitted).

5 See Gamble, 139 S. Ct. at 1964, including n.1. See also id. at 1998 (Gorsuch, J., dissenting) ("The statute under which the federal government proceeded required it to prove no facts beyond those Alabama needed to prove under state law to win its conviction; the two prosecutions were for the same offense."). One could disagree - claiming that the charged federal and state crimes each contain an element the other does not-but the argument seems unpersuasive and in any event was not made. See 18 U.S.C. $\S 922(\mathrm{~g})(1)$ (2012) (requiring "a crime punishable by imprisonment for a term exceeding one year" and also "affecting commerce"); ALA. CoDE § 13A-11-72(a) (2018) (incorporating diverse predicate offenses); $c f$. Torres v. Lynch, 136 S. Ct. 1619, 1630 (2016) (explicating "a settled practice of distinguishing between substantive and jurisdictional elements of federal criminal laws").

6 Bartkus, 359 U.S. at 155 (Black, J., dissenting). 
How did we arrive at this remarkable place? In the first instance, by traveling for over 150 years in a cursory and winding Supreme Court jurisprudence rich in dicta and light in analysis. ${ }^{7}$ But in 2019, it appeared we might get something better. Spurred by a recent concurrence of Justices Ginsburg and Thomas, ${ }^{8}$ the Court agreed to consider the duplicative prosecution of Gamble. Yet, in the end, only two Justices - Ginsburg and Gorsuch — would abandon the dual sovereignty doctrine. ${ }^{9}$ The other seven - with Justice Alito writing for the Court-were content with the status quo. ${ }^{10}$ Why "overrule a longstanding interpretation," the Court asked, when the constitutional text supports it, and the constitutional drafting history and pre- and post-founding caselaw are, at best, a muddle? ${ }^{11}$

The answer, we submit, is twofold. First, as we explain in Part III, the constitutional text does not support a dual sovereignty exception. ${ }^{12}$ The Court's strained reading not only seems unlikely as a matter of plain text, ${ }^{13}$ but it critically

7 See Gamble, 139 S. Ct. at 2006-08 (Gorsuch, J., dissenting) (analyzing and criticizing this jurisprudence); Bartkus, 359 U.S. at 159-60 (Black, J., dissenting) (same); Brief of Amici Curiae Criminal Procedure Professors Stephen E. Henderson, George C. Thomas III, Michael J. Z. Mannheimer, and Kiel Brennan-Marquez In Support of Petitioner at 23-31, Gamble v. United States, 139 S. Ct. 1960 (2019) (No. 17-646) (same). In a nutshell, it seems to us that (1) dual sovereignty doctrine first arose in moments of historical crisis (slavery and then prohibition) and because the Fifth Amendment had not yet been incorporated to bind the states; that (2) by the time of incorporation, the Court had become sufficiently accustomed to dual sovereignty to think it necessary to give each jurisdiction 'room' to protect its interests; but that (3) once the Court ultimately defined "same offence" so narrowly and jurisdictions passed so many criminal laws (with federal criminal enforcement expanding most notably), that policy concern lost any persuasive value it might have had.

8 See Sanchez Valle, 136 S. Ct. at 1877 (Ginsburg, J., dissenting) ("I write only to flag a larger question that bears fresh examination in an appropriate case . . . . Current 'separate sovereigns' doctrine hardly serves [double jeopardy's] objective.”).

9 See Gamble, 139 S. Ct. at 1989 (Ginsburg, J., dissenting); id. at 1996 (Gorsuch, J., dissenting).

10 See id. at 1964 ("Today we affirm [our dual sovereignty] precedent.”).

11 See id. at 1963.

12 We thus add our criticism to the rich literature critiquing the dual sovereignty rule. See, e.g., J.A.C. Grant, The Lanza Rule of Successive Prosecutions, 32 CoLuM. L. REV. 1309, 1331 (1932) (ably arguing against the rule and poignantly asking, "[s]hall we fritter away our liberties upon a metaphysical subtlety, two sovereignties?"); Paul G. Cassell, The Rodney King Trials and the Double Jeopardy Clause: Some Observations on Original Meaning and the ACLU'S Schizophrenic Views of the Dual Sovereign Doctrine, 41 UCLA L. REV. 693, 709-19 (1994) (developing an originalist critique of the rule); Akhil Reed Amar \& Jonathan L. Marcus, Double Jeopardy Law After Rodney King, 95 CoLUM. L. REV. 1, 4-27 (1995) (arguing against the general rule but for an exception when state officials violate federal civil rights). As Anthony Colangelo has noted, "it is hard to find any commentary that is not critical." Anthony J. Colangelo, Double Jeopardy and Multiple Sovereigns: A Jurisdictional Theory, 86 WASH. UNIV. L. REV. 769, 773 (2009).

13 It is, indeed, "a peculiar way to look at the Double Jeopardy Clause." Gamble, $139 \mathrm{~S}$. Ct. at 1991 (Ginsburg, J., dissenting). 
relies upon flawed logic, and it ignores the legitimate, limited justifications for criminal punishment. A great deal could be said about this, but we primarily rely upon literary theory, considering the ideal readers of the Gamble Court's opinions and the communities those opinions would create, and comparing them to the Framers' conception of citizenry and the constitutional community they intended. Second, as we explain in Part IV, Gamble was dual sovereignty's easiest case. Even were we wrong in Part III-meaning even if there should be a dual sovereignty exception in cases of truly foreign prosecutions - there would be no exception in the United States/constituent state instance, for as between the United States and Alabama, there is only one entire sovereign prosecutor. Thus, not even dual sovereignty doctrine rightly permits what our governments inflicted upon Terance Gamble.

\section{THE DOUBLE JEOPARDY RIGHT}

Before considering any dual sovereignty exception, we ought to articulate at least the core of the double jeopardy protection. According to Blackstone, it was a "universal maxim of the common law ... that no man is to be brought into jeopardy of his life more than once for the same offence." "And hence it [was] allowed as a consequence, that when a man [was] once fairly found not guilty upon any indictment or other prosecution, before any court having competent jurisdiction of the offence, he may plead such acquittal in bar of any subsequent accusation for the same crime." 15 The same went for a previous conviction, ${ }^{16}$ meaning the double jeopardy protections of the Fifth Amendment were very familiar to those of the founding generation. ${ }^{17}$

Even without that familiarity, the right would be intuitive to a free people. As the Supreme Court has explained, "the State with all its resources and power should not be allowed to make repeated attempts to convict an individual for an alleged offense, thereby subjecting him to embarrassment, expense and ordeal and compelling him to live in a continuing state of anxiety and insecurity." 18 Double

144 William Blackstone, Commentaries on the Laws of England 335 (1773).

15 Id.

16 See id. at 336. Thus, in the words of the Supreme Court:

$\mathrm{Th}$ [e double jeopardy] guarantee has been said to consist of three separate constitutional protections. It protects against a second prosecution for the same offense after acquittal. It protects against a second prosecution for the same offense after conviction. And it protects against multiple punishments for the same offense.

North Carolina v. Pearce, 395 U.S. 711, 717 (1969).

17 Again, the Clause provides that "[n]o person shall be... subject for the same offence to be twice put in jeopardy of life or limb." U.S. CONST. amend. V.

18 Green v. United States, 355 U.S. 184, 187 (1957). Double jeopardy, then, protects against what might be termed a "Sword of Damocles" problem. See Kiel Brennan-Marquez \& Stephen E. Henderson, Fourth Amendment Anxiety, 55 AM. CRIM. L. REV. 1, 25 (2018); see also 
jeopardy respects the finality of judgments, minimizes citizen anxiety, guards against erroneous convictions, respects jury nullifications, encourages efficient investigation and prosecution, and impels effective communication between coordinate governments. ${ }^{19}$ In short, a world without a double jeopardy limitation would be one only a tyrant (and his contented minion) could abide.

This is not to say that application of the right is without complication; application of a right never is. ${ }^{20}$ On the one hand, it is obvious that a person acquitted of a particular murder cannot be prosecuted again for that same murder. And it is obvious that an acquittal for a 2009 shooting ought to have no effect on a prosecution for a 2019 stabbing, even though both are prosecuted as murder. ${ }^{21}$ But what of an acquittal for a bank robbery followed by a prosecution for a simultaneous assault? Should the determination of "same offence" ask whether identical conduct, however defined, is being prosecuted, ${ }^{22}$ or should it instead look - as the Supreme Court has decided-solely to the elements of each prosecuted crime? ${ }^{23}$ And if looking solely to those elements, how strict an identity should be required? Should two crimes

Arnett v. Kennedy, 416 U.S. 134, 231 (1974) (“[T]he value of a sword of Damocles is that it hangs - not that it drops.”) (Marshall, Douglas, \& Brennan, JJ., dissenting).

19 See David S. Rudstein, Retrying the Acquitted in England, Part I: The Exception to the Rule Against Double Jeopardy for “New and Compelling Evidence”, 8 SAN DiEGo INT'L L.J. 387, 403-18 (2007) (developing these benefits).

20 For one, while we might favor an absolute bar, a double jeopardy limitation could operate with carefully limited exception. See, e.g., id. at 392-97 (explaining a 2003 British law allowing for limited exception upon new and compelling evidence). It has been urged "that God does not punish twice for the same act" (id. at $401 \mathrm{n} .67$ ), but then a god - unlike us — definitionally gets it right the first time. And among important matters not relevant to this paper, one must decide when jeopardy attaches and ends, and what constitutes 'punishment' such that one is "in jeopardy of life or limb." U.S. CONST. amend $\mathrm{V}$.

21 The crime of murder is, of course, the same crime as murder (the same definitional offense), but, just as obviously, one killing is not the "same offence" as an entirely different killing on a different day. The two are different units of prosecution.

22 See Grady v. Corbin, 495 U.S. 508, 510 (1990) ("We hold that the Double Jeopardy Clause bars a subsequent prosecution if, to establish an essential element of an offense charged in that prosecution, the government will prove conduct that constitutes an offense for which the defendant has already been prosecuted.") (emphasis added), overruled by United States v. Dixon, 509 U.S. 688, 703 (1993). A number of state courts continue to adhere to something like a Grady conduct analysis. See, e.g., State v. Swick, 279 P.3d 747, 754 (N.M. 2012) (rejecting a test "so mechanical that it is enough for two statutes to have different elements.").

23 See United States v. Dixon, 509 U.S. 688, 703 (1993) (overruling Grady in favor of the earlier Blockburger test); Brown v. Ohio, 432 U.S. 161, 166-70 (1977) (applying the Blockburger sameelement test to constitutionally bar a second prosecution); Gore v. United States, 357 U.S. 386, 39293 (1958) (applying the Blockburger same-element test to constitutionally permit a second prosecution); Blockburger v. United States, 284 U.S. 299, 304 (1932) (articulating the same-element test). 
constitute the same offense only if - again, as the Supreme Court has decided - they are elementally identical, ${ }^{24}$ or should we employ a more generous rule?

These are hard questions, and we are less than satisfied with existing answers. But none of these complications matter here. As for the prosecutions of Terance Gamble, everyone conceded that Alabama and then the United States charged and tried the same conduct, the same facts, under elementally identical crimes. ${ }^{25}$ That second prosecution therefore ran afoul of the Fifth Amendment unless permitted by a dual sovereignty exception. ${ }^{26}$

\section{CONSTITUTIONAL TEXT, COMMUNITY, AND DUAL SOVEREIGNTY}

Just what is the power of a sovereign when it comes to criminal punishments? On this, a great deal could be (and has been) said. One might look to social contract theory, in which the people collectively transfer some inherent rights in return for security guarantees. ${ }^{27}$ On that theory, state action outside of the bargain is an illegitimate breach. And with states thus empowered to criminally punish only for retributive and/or consequentialist gains, ${ }^{28}$ it would seem hard to imagine how-in

24 See Blockburger, 284 U.S. at 304 ("The applicable rule is that where the same act or transaction constitutes a violation of two distinct statutory provisions, the test to be applied to determine whether there are two offenses or only one, is whether each provision requires proof of a fact which the other does not.").

25 See Gamble v. United States, 139 S. Ct. 1960, 1964 n.1 (2019); id. at 1998 (Gorsuch, J., dissenting) ("The statute under which the federal government proceeded required it to prove no facts beyond those Alabama needed to prove under state law to win its conviction; the two prosecutions were for the same offense.").

26 See Moore v. Illinois, 55 U.S. 13, 18-20 (1852) (articulating the dual sovereignty principle); Bartkus v. Illinois, 359 U.S. 121, 138-39 (1959) (permitting a state prosecution following a federal prosecution); Abbate v. United States, 359 U.S. 187, 196 (1959) (permitting a federal prosecution following a state prosecution); United States v. Wheeler, 435 U.S. 313, 330-32 (1978) (permitting a federal prosecution following a Native American prosecution); Heath v. Alabama, 474 U.S. 82, 93 (1985) (permitting a state prosecution following that of another state). But see Waller v. Florida, 397 U.S. 387, 394-95 (1970) (holding that a municipality is not a separate sovereign from its state); Puerto Rico v. Sanchez Valle, $136 \mathrm{~S}$. Ct. 1863, 1876-77 (2016) (holding that Puerto Rico is not a separate sovereign from the United States government).

27 See generally Celeste Friend, Social Contract Theory, InTERnEt EnCYCLOPEDIA OF Philosophy, https://www.iep.utm.edu/soc-cont/ (last visited Feb. 20, 2020); Ann Cudd \& Seena Eftekhari, Contractarianism, The Stanford Encyclopedia of Philosophy (Summer 2018 Edition) (Edward N. Zalta ed.), https://plato.stanford.edu/archives/sum2018/entries/contractarianism/; Fred D'Agostino et al., Contemporary Approaches to the Social Contract, The STANFord EnCyClopedia OF Philosophy (FALl 2019 EDition) (Edward N. Zalta ed.), https://plato.s tanford.edu/archives/fall2019/entries/contractarianism-contemporary/.

28 See generally Hugo Adam Bedau \& Erin Kelly, Punishment, The STANFORD ENCYCLOPEDIA OF Philosophy (Winter 2019 Edition) (Edward N. Zalta ed.), https://plato.s tanford.edu/archives/win2019/entries/punishment/. 
mine-run cases - a second sovereign could justify inflicting a duplicative punishment. Whatever the alleged need (whether it be retributive; generally deterring by intimidation, education, or norm-reinforcement; or specifically deterring by intimidation, incapacitation, or rehabilitation), that need should have been fulfilled by the first prosecution and punishment. Only in the edge case, thenperhaps the first prosecution was a sham concocted by a corrupt government or an acquittal was caused by a particularly invidious bias-might legitimate governmental needs require further redress. ${ }^{29}$ Outside of that rare exception, any second-sovereign prosecution not only would disrespect the individual rights of the defendant, but would seem to impugn the very sovereignty of the first-moving state. $^{30}$

By contrast, a broad conception of dual sovereignty like that favored by the Gamble Court seems to relish criminal punishments. Each and every state gets to swing its own bat at the alleged offender, as if criminal punishment were a game of pinata that countries play. ${ }^{31}$ After all, "[w]e may lack confidence in the competence or honesty of [another] country's legal system"32 ... as if our systems were brimming with the same. ${ }^{33}$

What could explain this divergence? When our intuitions of government so strongly favor a robust double jeopardy protection with (at most) a narrow sham exception, ${ }^{34}$ how could seven Justices of the Supreme Court hold to the contrary?

29 Justice Black invoked just such a limited exception in his Bartkus dissent. See Bartkus v. Illinois, 359 U.S. 121, 161 (1959) (Black, J., dissenting) ("Sham trials, as well as those by courts without jurisdiction, have been considered by courts and commentators not to be jeopardy, and might therefore not bar subsequent convictions."). Inspiration for such an exception might be drawn from existing international agreements, like that limiting the jurisdiction of the International Criminal Court. See Rome Statute of the International Criminal Court Art. 17(2), available at https://www.icccpi.int/resource-library/Documents/RS-Eng.pdf. Still, hard work remains: what of racially motivated acquittals, or politically motivated ones? Because we are here concerned with the central rule rather than the edge case, we leave the particulars of a sham (no jeopardy) exception to future work.

30 This is intuitive in good parenting: a child already punished by one parent ought not be again punished by the other, and if the child nonetheless is, that second, in-the-wrong parent is likely to hear of it not only from the child but also from the disrespected, first-moving parent.

31 See Gamble, 139 S. Ct. at 1967 ("The principle comes into still sharper relief when we consider a prosecution in this country for crimes committed abroad."). See also Part III(B), infra.

32 Gamble, 139 S. Ct. at 1967.

33 One might invoke the spirit of a famous Biblical passage, namely the hypocrisy of claiming to clearly see another's minor faults while overlooking one's own major flaws. See Matthew 7:3-5.

34 As for international law, we speak only normatively to what the law ought to be. For readers interested in existing international law, we recommend the work of Anthony J. Colangelo, who concludes that "[i]nternational instruments and state practice seem to point in so many directions at once that the international law of double jeopardy looks to be nothing more than a jumbled mess of partial and often inconsistent rules implying a general doctrinal incoherence." Anthony J. Colangelo, Double Jeopardy and Multiple Sovereigns: A Jurisdictional Theory, 86 WASH. UnIV. L. REV. 769, 774 (2009). See also id. at 806-15 (gathering international agreements, which 
We believe the Court began in the wrong place. It took dual sovereignty doctrine as a given - based partly upon some flawed logic — and then it asked whether there was reason to dismiss it based upon constitutional drafting history and early law. ${ }^{35}$ The Court instead should have begun with the plain textual interest of prosecuted defendants, or of Americans generally. We first tackle the Court's error in logic, and then turn to basic literary theory in an attempt to understand and explain the Court's inversion of priority.

\section{A. The Court's Syllogistic Error}

The Gamble Court, in an opinion written by Justice Alito, immediately stumbled by employing an elementary error of logic. In the Court's words,

We start with the text of the Fifth Amendment. ["No person shall be ... subject for the same offence to be twice put in jeopardy of life or limb."] Although the dual-sovereignty rule is often dubbed an "exception" to the double jeopardy right, it is not an exception at all. On the contrary, it follows from the text that defines that right in the first place.... [A]n "offence" is defined by a law, and each law is defined by a sovereign. So where there are two sovereigns, there are two laws, and two "offences." 36

The Court thus alleged two premises, both of which appear to be true:

Premise 1: An offense is defined by a law.

Premise 2: Each law is defined by a sovereign.

Stating these in conditional form, ${ }^{37}$

typically incorporate a dual sovereignty exception); $i d$. at 817-19 (gathering particular state laws which cut both ways); see also Anthony J. Colangelo, Gamble, Dual Sovereignty, and Due Process, 2019 CATO S. CT. REV. 189 (2019) (hereinafter "Colangelo, Gamble") (updating his personal theory post-Gamble, which is that due process limitations on subsequent prosecutions ought to temper the dual sovereignty exception).

To be clear, we do not here take issue with any claimed principle granting a particular state criminal jurisdiction. See, e.g., Colangelo, Gamble at 208-09 (explaining accepted bases of jurisdiction). What we reject is the notion that those principles apply with the same force-or really much of any force-when a coordinate jurisdiction similarly satisfying one of them has already prosecuted this very defendant for this very crime.

35 See, e.g., Gamble, 139 S. Ct. at 1974 (“[Gamble's treatise-based arguments] do not come close to settling the historical question with enough force to meet Gamble's particular burden under stare decisis.").

36 Id. at 1965.

37 We have toyed with the proposition that the Court was saying (or was trying to say) something different, but we cannot derive a plausible alternative that logically fares any better. 
Premise 1: If something is an offense, then it is defined by law. $[P \rightarrow Q]$.

Premise 2: If something is a law, then it is defined by a sovereign. [ $Q \rightarrow$ $R]$.

Having two true statements, we can conclude with a valid, sound syllogism: If something is an offense, then it is defined by a sovereign $[\therefore P \rightarrow R]$. Wonderful. Only this does not work, because nobody is claiming the federal government and Alabama - the two entities that prosecuted Gamble - are not sovereigns. So, unfortunately, the Court concluded something quite different: "So where there are two sovereigns, there are two laws, and two "offences" $[R \rightarrow Q \rightarrow P]$. This is the converse error (or, if one prefers, the fallacy of affirming the consequent), and it of course gets no better because the Court multiplied each premise by two. ${ }^{38}$

While it is enough to demonstrate the invalidity of the Court's argument, it might help to demonstrate by example what that argument would entail. Rather than laws, let's think a bit about their components, words:

Premise 1 [Court form]: A word is defined by a dictionary.

Premise 2 [Court form]: A dictionary is defined by a publisher.

Premise 1 [Alternate form]: If something is a word, then it is defined by a dictionary.

Premise 2 [Alternate form]: If something is a dictionary, then it is defined by a publisher.

By the Court's (flawed) logic, then, where there are two publishers, there are two dictionaries, and two words. ${ }^{39}$ So, to the Court, there must be 'Merriam-Webster cats' that are not to be confused with 'Oxford English Dictionary (OED) cats,' and 'Merriam-Webster dogs' that should not be confused with the OED variant. When talking about the typical quadrupeds these words describe, that's just silly. Of

38 Justice Gorsuch notes the Court's flawed logic in his dissent, but he a bit confusingly tries to simultaneously declare both the invalidity of that argument and an attempted proof of the opposite conclusion. See Gamble, 139 S. Ct. at 1997-98 (Gorsuch, J., dissenting).

39 One might object that words are not actually defined by dictionaries (and thus by publishers); instead, those works merely declare what have already become words by, say, conventional usage. But this objection does no work for two reasons. First, the same could beand indeed in natural law constructs often is - said of the law, meaning the example still parallels the Court's own. Second, because the Court's argument is invalid, it is irrelevant whether its premises are true. Hence, the following example works just as well even if there are in fact no gods:

Premise 1: A sin is defined by religion.

Premise 2: A religion is defined/declared by a god.

Court's bogus conclusion: So where there are two gods, there are two religions, and thus two sins.

Murder can still be murder, even if two gods independently, identically dislike it. 
course, there sometimes will be two words, because any publisher might define a term uniquely_ perhaps only one sees cats as 'cool' and dogs as 'loyal.' But it would be absurd to assert that every word in one dictionary is different from every word in the other.

Which, of course, is equally true of laws. Sometimes a law of the federal government will be different from a law of Alabama, and we have the Blockburger test to define when that is so. ${ }^{40}$ But sometimes the two laws will be the same, as everyone agreed the two crimes were in Gamble: each jurisdiction decided to punish the possession of a firearm by a felon. ${ }^{41}$

\section{B. The Ideal Reader}

So, the Court relied upon a bit of flawed logic. That hardly explains, however, its entire interpretation of the Fifth Amendment's Double Jeopardy Clause text. In an effort to understand the broader mistake, we turn to some literary theory. ${ }^{42}$ Every text, no matter how short, ${ }^{43}$ invites creation of at least one community. The writing of judges and lawyers is 'constitutive' in this sense: legal texts help to constitute communities by their rhetoric or language. ${ }^{44}$ Of course, created communities - even those formed from a single text — need not be identical, and indeed might have

40 According to the Blockburger rule, two offenses are not the same if each contains an element that the other does not. See Blockburger v. United States, 284 U.S. 299, 304 (1932). We are hardly fans of this definition, but that is a matter for another day.

41 This is not to say an argument could not be made based upon the particular text of each statute that they are in fact not the same Blockburger offense. But that argument was never made (see Gamble, 139 S. Ct. at 1964 n.1), and so we need not pursue it here. See also Gamble, 139 S. Ct. at 1964, including n.1. See also id. at 1998 (Gorsuch, J., dissenting) Once again, Gamble was the easiest case in which to demonstrate the error of dual sovereignty.

42 See generally Vince Brewton, Literary Theory, INTERNET ENCYCLOPEDIA OF Philosophy, https://www.iep.utm.edu/literary/ (last visited Feb. 20, 2020).

43 All of Gamble concerns twenty words, only one of those extending to three syllables: "[N]or shall any person be subject for the same offence to be twice put in jeopardy of life or limb .... " U.S. CONST. amend. V. In that score of words, only the longest- "jeopardy"-is arguably outside ordinary usage, with a special meaning in law and a complex history. See Jay A. Sigler, A History of Double Jeopardy, 7 Am. J. Legal Hist. 283 (1963); Jay A. Sigler, Double Jeopardy: The Development of A Legal And Social Policy 4-37 (1969). The Gamble majority, however, takes another word"offence" - outside of ordinary usage. Compare Gamble, 139 S. Ct. at 1965 (majority opinion) (making the syllogistic error described above and citing cases, a 1792 legal dictionary, and a 1730 British dictionary); with id. at 1997-9 (Gorsuch, J., dissenting) (objecting to the syllogistic error and explicitly invoking the perspective of "an ordinary reader of the Fifth Amendment"); and id. at 1989 (Ginsburg, J., dissenting) (offering a non-technical reading of "offence" and objecting to idea that "identical criminal laws enacted by 'separate sovereigns' are different 'offence[s]"').

44 James Boyd White is prominent among scholars who have applied literary theory to law in this way. See, e.g., James Boyd White, Heracles' Bow: Essays on the Rhetoric and Poetics of THE LAW 34-35, 37-39 , 70-72 (1985); JAMES Boyd White, Justice As Translation: An Essay in Cultural and Legal Criticism xiv, 99-102, 203 (1990). 
relatively little overlap. ${ }^{45}$ In law, though, even seemingly separate communities should share a greater bond, tied together in a "culture of argument" that promotes genuine thought and meaning. ${ }^{46}$ And the United States Constitution was literally designed to create or constitute a single, large community: a nation. Its drafters debated, in writing and in spoken word, what kind of community that would be. ${ }^{47}$ And the project of defining, creating, and recreating that community has continued ever since, including in every new judicial decision on constitutional meaning, in every brief that lawyers submit on such questions, and in every article that scholars pen.

These many arguments proceed through competing interpretive theories, no one of which - whether formalist, realist, or pragmatic - ever has won the day, or even has crowded out the others. We continue to dispute not just what the Constitution means, but how methodologically to approach that question of meaning. In Gamble, two self-avowed 'strict constructionists'-Justice Alito for the majority and Justice Gorsuch in dissent-arrived at diametrically opposed understandings of the short Double Jeopardy Clause. ${ }^{48}$ Although each claimed to

45 Metaphorically, two rings of people may encircle separate campfires, both reciting the same story, but with different understandings of meaning. An orthodox Jewish congregation, say, and a Southern Baptist congregation each may study and honor a passage in Deuteronomy, despite differences in understanding the text and the context in which it is situated.

46 White, Heracles' Bow, supra note 44 at 32-35, 78. See also James Boyd White, Living SPEECH: RESISTING THE EMPIRE OF FORCE 72-77, 210-13 (2006) (making the same point at a higher level of generality). White does not use the phrase "culture of argument" derisively. Instead, he celebrates a proper culture of argument and means it to indicate the highest ethical work of lawyers.

47 A principal debate before, during, and after the Constitutional Convention was that between federalist and anti-federalist factions. Merely an edited and selective record of that debate fills five large volumes and 3,260 pages. The Founders' Constitution (Philip B. Kurland \& Ralph Lerner, eds., 1987). The Library of Congress has many more delegate papers and contemporary commentary. The most famous set of written arguments, The Federalist Papers, was published at the time in series. This collaborative work of John Jay, Alexander Hamilton, and James Madison, writing under one pseudonym, ran to eighty-five installments. But many anti-federalists also wrote at the time, again often pseudonymously. In the twentieth century, some of these writings were collected too. The first major effort, by Morton Borden, chose a parallel eighty-five writings. THE ANTIFEDERALIST PAPERS 2 (Morton Borden, ed., 1965). A later, more expansive effort resulted in seven volumes and 1,741 pages of antifederalist writings, not including notes and front matter. THE COMPLETE ANTI-FEDERALIST (Herbert J. Storing \& Murray Dry, eds., 1981). But these various sources only scratch the surface, of course, because the oral debates over five months of the convention and over many months of state ratification debates were not transcribed consistently or verbatim.

48 See, e.g., Confirmation Hearing on the Nomination of Samuel A. Alito, Jr. to be an Associate Justice of the Supreme Court of the United States, S. Hrg. 109-277, 109 Cong., 2d Sess., at 429 (S. Judiciary Comm., January 9-13, 2006) ("Well, if a strict constructionist is a judge who doesn't make things up, then I'm a strict constructionist."); Neil M. Gorsuch, Why Originalism is the Best Approach to the Constitution, Time (Sept. 6, 2019) https://time.com/5670400/justice-neil-gorsuch-why-originalism-is-the-best-approach-to-theconstitution/ (last visited Dec. 7, 2019) (explaining his philosophy).

Both have demonstrated this approach in their opinions for the Court. See, e.g., McDonald v. City of Chicago, 561 U.S. 742, 767-78 (2010) (Justice Alito for the Court, surveying the 
discern the plain meaning, ${ }^{49}$ their writings call into being two very different communities. ${ }^{50}$ They beckon or conjure two different ideal readers. ${ }^{51}$ In other words, they appeal to people of two very different qualities of character, and offer two very

evidence that the Second Amendment rights are fundamental to our ordered liberty and deeply rooted in history and tradition); Janus v. AFSCME, Council 31, 138 S. Ct. 2448, 2470 (2018) (Justice Alito, again for the Court, asserting tartly that the majority would not engage in "halfway originalism"); Town of Greece, N.Y. v. Galloway, 572 U.S. 565, 600-03 (2014) (Alito, J., concurring) (surveying founding-era history and practice and concluding that Christian prayer opening Town Board meetings did not violate the First Amendment's Establishment Clause); Food Marketing Institute v. Argus Leader Media, 139 S. Ct. 2356, 2362-64 (2019) (Justice Gorsuch for the Court, seeking the plain meaning of a critical term in FOIA as enacted in 1966; chiding the court below for "casual disregard of the rules of statutory interpretation," and calling an earlier circuit precedent "a relic from a "bygone era of statutory construction" because it "inappropriately resort[ed] to legislative history before consulting the statute's text and structure"); Henson v. Santander Consumer USA, Inc., 137 S. Ct. 1718, 1726 (2017) (Justice Gorsuch for a unanimous Court; after determining conventionally the meaning of a disputed statutory term, reminding that "the proper role of the judiciary" is "to apply, not amend, the work of the People's representatives"). See also Steven G. Calabresi \& Todd W. Shaw, The Jurisprudence of Justice Samuel Alito, 87 Geo. WASH. L. REv. 507, 526 (2019) (describing Alito's jurisprudence as "indeed originalist, though not in the traditional sense").

49 Contrast Gamble, 139 S. Ct. at 1966 (majority opinion claiming "fidelity to the Double Jeopardy Clause's text"), and $i d$. at 1965 (majority insisting that it took the term "offence" as "originally understood"); with id. at 1997 (Gorsuch, J., dissenting) (claiming adherence to the text's "seemingly plain command"), and $i d$. at 1996 (Gorsuch, J., dissenting) (contending that the majority's reading "finds no meaningful support in the text of the Constitution, its original public meaning, structure, or history").

50 Rather than consider it independently, we include Justice Ginsburg's dissent in our discussion of Justice Gorsuch's opinion, for hers creates a community consistent with his. See Gamble, 139 S. Ct. at 1989-96 (Ginsburg, J., dissenting).

51 The 'ideal reader' is a construct of literary criticism dating at least to the 1970s. See generally Robert DeMaria, Jr., The Ideal Reader: A Critical Fiction, 93 PMLA 463 (1978). The concept, correctly understood, is not really demographic: it is not about, for example, sex, age, education, socioeconomic status, or even reading tastes or interests. Rather, it concerns character or intrinsic qualities: habits of mind, ethics, and values. See id. Unsurprisingly, the role and nature of the ideal reader are subjects of debate in the world of literary criticism. See, e.g., Didier Coste \& Richard Brautigan, Three Concepts of the Reader and Their Contribution to a Theory of the Literary Text, 34 ORBIS LITTERARUM 271 (1979) (attempting to make sense of certain critiques). But most important for our purposes, the ideal reader need not be an admirable person; the term "ideal" does not carry that sense here. A text may invoke an ideal reader who is greedy, blindly obedient, unthinking, selfish or otherwise unappealing, just as it may invoke the opposite. See C.R.B. Dunlop, Literature Studies in Law Schools, 3 CARDOzo STUdies IN L. \& Lit. 63, 85 (1991) (explaining that "[a] text defines an ideal reader whom the actual reader is invited to become" and using a racist joke as an example of an invitation one might decline). In the context of law as an inescapably literary activity, James Boyd White refers often to the ideal reader, for the writer of any text creates or calls upon an ideal readerwhether consciously or not - by the character she expresses in her act of writing. See, e.g., White, Justice As Translation, supra note 44 at 100-01. 
different opportunities to enact character in reading a judicial opinion. These differences relate to humilitas, the Latin noun at the root of English words relating to humility. $^{52}$

\section{A People Humbled Before Government}

Rather than interpret the Double Jeopardy Clause as an individual's guarantee against overreaching government, the Gamble majority flips it into an enabling clause for that same government, establishing and protecting sovereign prerogative against the citizen. No longer is the Fifth Amendment the citizen's shield; now it is the sovereign's sword. And with the emphasis thus on sovereign prerogative, the onus is on the citizen to rebut a presumption of governmental power to do as it pleases. Any gap in the historical record, then, presumptively favors the government, not the people who simultaneously empowered and limited it.

Despite superficial attention to minute historical detail-the Court went through the motions of a labored explication of old British and American casesthe majority wrote a deeply ahistorical story. And it did so with brio, alleging that Gamble's own contrary interpretation was based "in legend, not case law." ${ }^{33}$ That sneer fails to acknowledge that the historical precedents are at least unclear, ${ }^{54}$ and fails to ask a more fundamental question: what did the Framers believe about that historical record? The Court was similarly dismissive regarding the undeniableeven exponential - spread of federal criminal jurisdiction over the past decades, ${ }^{55}$ when changed circumstances frequently figure into application of stare decisis. ${ }^{56}$

52 The Latin noun means low position or rank, baseness, or submissiveness. See OXFORD LATIN DiCTIONARY (1982). It in turn comes from humus, meaning ground or soil. Id.

53 Gamble, 139 S. Ct. at 1974.

54 See, e.g., Brief of Amici Curiae Law Professors In Support of Petitioner 3-6, Gamble v. United States, 139 S. Ct. 1960 (2019) (No. 17-646) (urging the contrary reading).

55 See, e.g., Overcriminalization, THE HERITAGE FounD., https://www.heritage.org/crime-andjustice/heritage-explains/overcriminalization (last visited Feb. 21, 2020) ("Over the past 40 years, federal criminal law has exploded in size and scope while deteriorating in quality."); Overcriminalization, NAT'L ASS'N OF CRIM. DEF. LAW., https://www.nacdl.org/Landing /Overcriminalization (last visited Feb. 21, 2020) ("With over 4,450 crimes scattered throughout the federal criminal code, and untold numbers of federal regulatory criminal provisions, our nation's addiction to criminalization backlogs our judiciary, overflows our prisons, and forces innocent individuals to plead guilty not because they actually are, but because exercising their constitutional right to a trial is prohibitively expensive and too much of a risk.").

56 Compare Gamble, 139 S. Ct. at 1979-80 (explaining and dismissing the argument in two short paragraphs), with id. at 1981 ("The Court currently views stare decisis as a "principle of policy' that balances several factors to decide whether the scales tip in favor of overruling precedent.") (Thomas, J., concurring). Those factors include the "workability" of the existing rule, which is of course responsive to changed circumstances. See id. at 1981 (Thomas, J., concurring); Montejo v. Louisiana, 556 U.S. 778, 792 (2009) ("[T]he fact that a decision has proved 'unworkable' is a traditional ground for overruling it."). 
Instead of grappling with this recent reality, the Court asserted that "[e]liminating the dual-sovereignty doctrine would do little to trim the reach of federal criminal law, and it would not even prevent many successive state and federal prosecutions for the same criminal conduct." ${ }^{, 57}$ But if the impact of double prosecutions is minimal either way, why not opt for cropping just a bit of the overgrowth of federal criminal jurisdiction, rather than enlarging it still a bit further? Only an inverted conception of the Bill of Rights as empowering government, as opposed to confining and delimiting sovereign power, could justify such a dismissive response.

And that view has profound implications. As just one example, consider the pairing of modern habeas corpus jurisprudence (after the Antiterrorism and Effective Death Penalty Act of $1996^{58}$ ) with Gamble's reaffirmation of the dual sovereignty doctrine. Under current habeas rules, state-court rulings on federal constitutional questions that are wrong must stand on federal collateral review, unless they are unreasonably wrong - no fair-minded judge could come to the state court's mistaken conclusion. ${ }^{59}$ Dubious state-court fact findings stand, too, and cannot even be retested with further evidence, unless they are wholly unsupported in the record. ${ }^{60}$ And finality is the presumption of the day: even a pro se inmate has only one year from the date on which his state conviction is "final" to file a facially-sufficient petition in federal court, and he ordinarily may file only once. ${ }^{61}$ Thus, state governments now enjoy greater respect for the finality of their criminal judgments on federal review, even when marred by federal constitutional error, than citizens enjoy respect for the finality of state criminal judgments against (or for) them on

57 Gamble, 139 S. Ct. at 1980.

58 Antiterrorism and Effective Death Penalty Act, Pub. L. No. 104-132, 110 Stat. 1214 (1996) (codified in scattered sections of 28 U.S.C.).

5928 U.S.C. $§ 2254(\mathrm{~d})(1)$ ("An application for a writ of habeas corpus on behalf of a person in custody pursuant to the judgment of a State court shall not be granted with respect to any claim that was adjudicated on the merits in State court proceedings unless the adjudication of the claim... resulted in a decision that was contrary to, or involved an unreasonable application of, clearly established Federal law, as determined by the Supreme Court of the United States."). See Nevada v. Jackson, 569 U.S. 505, 508-09 (2013) ("It is settled that a federal habeas court may overturn a state court's application of federal law only if it is so erroneous that there is no possibility fairminded jurists could disagree that the state court's decision conflicts with this Court's precedents.") (quotation marks and citation omitted).

6028 U.S.C. $\S 2254(\mathrm{~d})(2)$ (“An application for a writ of habeas corpus on behalf of a person in custody pursuant to the judgment of a State court shall not be granted with respect to any claim that was adjudicated on the merits in State court proceedings unless the adjudication of the claim ... resulted in a decision that was based on an unreasonable determination of the facts in light of the evidence presented in the State court proceeding."). See Brumfield v. Cain, 135 S. Ct. 2269, 2277 (2015) ("We may not characterize these state-court factual determinations as unreasonable merely because we would have reached a different conclusion in the first instance.") (quotation marks and citation omitted).

6128 U.S.C. § 2244(b) (severely restricting "second or successive habeas corpus application[s]"); 28 U.S.C. $§ 2244$ (d) (establishing one-year statute of limitation). 
federal re-prosecution. We struggle to imagine any delegate involved in the debate over what became the Fifth Amendment approving of that comparative disadvantage.

The Gamble majority's conception finds the citizenry bowing humbly to the government: the individual must accept the lash not once, but twice, the duplication depending entirely on any second prosecutor's whim. Humility here is not for the government that administers punishment, the government that would deprive its citizen of liberty. Rather, humility is for the citizen. The ideal reader of the Court's opinion in Gamble, then, is a cowed citizen who accepts sovereign say-so, even when that means serving two consecutive punishments for the same offense.

Take Terance Gamble himself. A Mobile, Alabama, police officer chanced upon Gamble's gun after pulling his car over for a damaged headlight. ${ }^{62}$ Gamblea previously convicted felon-acknowledged guilt in a local court for this local offense. ${ }^{63} \mathrm{He}$ was sentenced to prison for a year. ${ }^{64}$ Only then the federal government decided that the state judge used too light a hand in sentencing. So, it prosecuted Gamble again, and a federal judge added almost four more years in prison. ${ }^{65}$ For all that appears, the federal government made no claim that a man with one good headlight and a gun put the Republic at risk unless a federal judge could impose a supplemental sentence. Rather, this was a case - like most double prosecutions - in which the second sovereign indicted simply because it could; because doing so scratched some prosecutorial itch. There was no humility of a government inflicting punishment or depriving a person of liberty. There was not even any parsimony. Instead, there was a citizen humbled again before a purported second sovereign, with a constitutional amendment designed to protect that citizen's liberty turned against him to mock his subservient position.

Note, too, that the federal government's lack of humility was not limited to its treatment of Terance Gamble. The high-handed treatment extended to the state of Alabama: a local judge's sentence on a local crime, investigated by local police, simply was not sufficient to suit the national government.

Neither Gamble nor the dual sovereignty doctrine that it reaffirms, then, are good examples of American federalism-of "political authority and power resid[ing] in the people, who delegate powers through constitutional devices to different governments serving different arenas for different purposes. ${ }^{\prime 66}$ Rather, they

62 See Gamble, 139 S. Ct. at 1964.

63 See id.

64 See Brief for Petitioner 2, Gamble v. United States, 139 S. Ct. 1960 (2019) (No. 17-646).

65 See id. at 3; Gamble, 139 S. Ct. at 1997 (Gorsuch, J., dissenting).

66 Daniel J. Elazar, Exploring Federalism 16 (1987). See Michael J. Zydney Mannheimer, Three-Dimensional Dual Sovereignty: Observations on the Shortcomings of Gamble v. United States, 52 TeX. TECH. L. REV. (forthcoming 2020) ("The Double Jeopardy Clause is only one provision of a larger project, the criminal procedure provisions of the Bill of Rights as a whole, which were adopted to assure the continuing primacy of the States in meting 
are examples of a conception of relation between sovereign and citizen cast in hubris of the former, and humble endurance of the latter. The Gamble majority constitutes a community in which the sovereign rejects limits on its prerogatives - rejects even a demand to explain or justify those prerogatives - and in which the citizenry submits to lesser liberty in the hope (but not the assurance) that freewheeling sovereign power and punishments will be condign.

That is not the community that the authors of the Bill of Rights imagined. They did not imagine ideal readers of the Constitution, or ideal citizens, as humbly subservient before an unbound and unreasonable sovereign. Indeed, they recently had fought a war to change exactly that.

\section{A Government Humbly Serving Its People}

Justices Ginsburg and Gorsuch, in contrast to the Gamble majority and in kinship with the Founders, call into being a very different community by their texts. They wrote for a very different ideal reader. To start, the two dissenters each welcomed the common citizen's viewpoint and understanding of language: for Ginsburg, the Double Jeopardy Clause simply does not tolerate " "unjust' prosecutions, ${ }^{\prime 67}$ and for Gorsuch, the "ordinary speaker of English" is who matters. ${ }^{68}$ Most importantly and explicitly, for both of them, the American people ultimately are sovereign, not their governments. ${ }^{69}$

Throughout both dissents, the statist orientation of the majority opinion is absent. Both dissents are grounded in recognition that the Court's project in Gamble was interpreting a clause of the Fifth Amendment, not interpreting, say, an ambitious act of legislation. As to the latter, a statist viewpoint might be fine: both state and federal governments may act robustly within defined legislative spheres, even when doing so trenches on liberty. ${ }^{70}$ Indeed, every statutory crime, every tax act, every act to protect government secrets, every law requiring mutual sacrifice for shared benefit, does exactly that. But the Fifth Amendment, like the whole of the Bill of Rights, instead curbs governmental power by every clause, usually by expressly negating government power to infringe specific freedoms and less often by affirmatively asserting positive rights. Nowhere is the Bill of Rights an enabling act for government. Rather, it disables the sovereign selectively, thus by implication enabling a free people.

out criminal justice. The Double Jeopardy Clause, like many of these provisions, is as much about federalism as it is about rights.").

67 Gamble, 139 S. Ct. at 1992 (Ginsburg, J., dissenting).

68 Id. at 1997 (Gorsuch, J., dissenting); see also id. at 1999 ("Imagine trying to explain the Court's separate sovereigns rule to a criminal defendant, then or now.").

69 See id. at 1990 (Ginsburg, J., dissenting); id. at 1999 (Gorsuch, J., dissenting).

70 See, e.g., U.S. CONST. art. I, $\S 8$ (enumerating federal powers). 
The statist perspective of the majority, then, simply is implausible. The dissents, by sharp contrast, adopt a plausible perspective: throughout, they explore what the citizenry reasonably might expect their governments to be disempowered from doing, not what government officials might demand they be empowered to do. $^{71}$

With that perspective, even in federalism sovereignty remains undivided, a sort of tenancy by the entirety residing in the citizenry: a mutual but unpartitioned claim. Only governmental functions are divided (between state and federal apparatuses), and in that division of delegated powers the sovereign citizenry retains its best hope that governments will serve the people, not the people their governments. For Ginsburg, quoting Alexander Hamilton in The Federalist No. 82, the United States and its constituent states are "kindred systems" that are but "parts of ONE WHOLE." "72 For Gorsuch, Alexander Hamilton also had it right, as did Chief Justice John Marshall when he explained that this nation "is emphatically, and truly, a government of the people, and all sovereignty emanates from them."73

Given the ambiguous and fragmentary quality of the common law precedent and early American cases, both Ginsburg and Gorsuch - the latter especiallyultimately resorted to burdens of persuasion, as did the majority. For both dissenters, though, the onus is on the government that would claim license under the Fifth Amendment, rather than on the citizen who would claim its protection. Ginsburg argued that incorporation of double jeopardy protection into the Fourteenth Amendment removed the rationale of early dual sovereignty decisions. ${ }^{74}$ Incorporation historically eliminated the gamesmanship of separate sovereignty as to the Fourth Amendment by scuttling the 'silver platter' doctrine: no longer could local police unbound by the prohibition on unreasonable searches and seizures simply turn over evidence to complicit federal authorities. ${ }^{75}$ And incorporation eventually eliminated the same gamesmanship as to the Fifth Amendment's Selfincrimination Clause: once the privilege against self-incrimination came to bind the states, they could not compel incriminating statements that the federal government

71 See, e.g., Gamble, 139 S. Ct. at 1991 (Ginsburg, J. dissenting) ("[Dual sovereignty] is a peculiar way to look at the Double Jeopardy Clause, which by its terms safeguards the 'person' and restrains the government.”).

72 Id. at 1990 (Ginsburg, J., dissenting) (quoting ThE FEDERALIST No. 82).

73 Id. at 1999 (Gorsuch, J., dissenting) (quoting McCulloch v. Maryland, 17 U.S. 316, 404-05 (1819)) (quotation marks omitted). As John Marshall there explained, "From these [constitutional] conventions, the constitution derives its whole authority. The government proceeds directly from the people." McCulloch, 17 U.S. at 403. Of course, for entirely practical reasons, those conventions were organized by state. "But the measures they adopt do not, on that account, cease to be the measures of the people themselves, or become the measures of the state governments." Id.

74 See Gamble, 139 S. Ct. at 1991 (Ginsburg, J., dissenting).

75 See id. at 1993-94 (Ginsburg, J., dissenting); Elkins v. United States, 364 U.S. 206 (1960). 
then might use to convict. ${ }^{76}$ So, incorporation ought to remove the same gamesmanship as to double jeopardy. For Ginsburg, "the Court [ought] to consider the protection against double jeopardy from the defendant's perspective and ... ask why each of two governments within the United States should be permitted to try a defendant once for the same offense when neither could try him or her twice."

Justice Gorsuch's dissent has an even sharper burden-of-proof cast. ${ }^{78}$ With the government unable to persuade Gorsuch on the historical record, it had only the doctrine of stare decisis on which to rely. And here Gorsuch's writing encapsulates the competing conceptions of the government's relation to its citizens: "After all," Justice Gorsuch noted, "judges swear to protect and defend the Constitution, not to protect what it prohibits." 79 The hope for governing with humility-rather than for a government that humbles its citizenry-lives in that understanding of the oath.

Terance Gamble could have found tyranny in many places. Unfortunately, he found a measure of it in a nation quick to pride itself for the opposite. Others will find the same while Gamble and the current dual sovereignty doctrine stand.

\section{FEDERALISM, IGNORED PRECEDENT, AND DUAL SOVEREIGNTY}

We believe, then, that the American double jeopardy protection was meant to exclude a dual sovereignty exception altogether. ${ }^{80}$ The community that the constitutional text intended will not admit of that exception, for the exception puts the power of the State before the rights of the citizen and could rather easily swallow the protection itself. But even if we are wrong, dual sovereignty would be limited to sovereigns truly foreign to one another. On this more limited view, a previous conviction or acquittal by, say, Portugal might not constitutionally bar a second prosecution by the United States. But, of course, Terance Gamble was not first

76 See id, 139 S. Ct. at 1994 (Ginsburg, J., dissenting); Murphy v. Waterfront Comm'n, 378 U.S. 52 (1964).

77 Gamble, 139 S. Ct. at 1994 (Ginsburg, J., dissenting).

78 See id. at 2000-05 (Gorsuch, J., dissenting).

79 Id. at 2005 (Gorsuch, J., dissenting).

80 Thus, we agree with what many make of the common-law precedent, including the (now unreported) King v. Hutchison. See, e.g., Gamble 139 S. Ct. at 2001-05 (Gorsuch, J., dissenting). The Gamble majority instead took solace in there not being "one reported decision barring a prosecution based on a prior trial under foreign law." Id. at 1970. But in dissent Justice Gorsuch was able to play the same card: neither is there "a single preratification common law authority approving a case of successive prosecutions by separate sovereigns for the same offense." Id. at 2002 (Gorsuch, J., dissenting). So, silence can cut either way, and if a type of prosecution offends ordinary, well-accepted principles of justice, we ought not be surprised to find them rarely or even (for long stretches) not at all. 
prosecuted by a foreign sovereign like Portugal; he was first prosecuted by Alabama. ${ }^{81}$

We argue this limitation on two grounds. One, logic and history demand it. And, two, the Court's own precedent-ignored in Gamble - seems to establish it.

\section{A. Our Founding History}

Before our constitutional founding, thirteen sovereigns stood along or near the Atlantic seaboard. ${ }^{82}$ Thus, Massachusetts and Pennsylvania, say, were situated much like Portugal and England. But through ratification of our Constitution, thirteen sovereigns chose to become one indivisible nation. ${ }^{83}$ So, just as a corporate merger leaves only a single corporation, ratification of our Constitution left only one sovereign. ${ }^{84}$ There is only one United States of America, as opposed to thirteen or fifty states united in some cause. This sole sovereignty is precisely why the northern states had law - and not mere military might — on their side during the Civil War: no constituent element had a right to leave this single whole. Thus, upon ratification, Massachusetts and Pennsylvania never again would be like Portugal and England.

That should decide the double jeopardy fate of, for example, a prosecution by Alabama followed by a duplicative (same offense) prosecution by Massachusetts. As a matter of history and Constitution, it cannot happen - at very least since the incorporation of the double jeopardy protection into the Due Process Clause of the Fourteenth Amendment. ${ }^{85}$ But what of the United States having chosen to divide its sovereignty among constituent parts in a federalist system ${ }^{86}$ Are things different when the first prosecution is by Alabama and then the second by the federal whole?

81 To the Gamble majority, Alabama is akin to Albania, albeit bound by the Double Jeopardy Clause. See Benton v. Maryland, 395 U.S. 784, 787 (1969) ("[W]e hold that the Double Jeopardy Clause of the Fifth Amendment is applicable to the States through the Fourteenth Amendment ....'); Gamble, 139 S. Ct. at 1978-79 (recognizing the same).

82 See AkHil ReEd Amar, AmericA's Constitution: A BIOGRAPHy 21-39 (2005) (explaining the post-revolution reality of separate sovereigns and the effect of our Constitution thereon). Properly understood, this separate sovereignty remained under the Articles of Confederation, just as it would under other classic international agreements. See id. at 25-28.

83 See id.

84 See id. at 21 ("Thus, the establishment of 'this Constitution' was not just the world's most democratic moment, but also, in a manner of speaking, the world's largest corporate merger.").

85 See Benton v. Maryland, 395 U.S. 784, 787 (1969) (incorporating the right). Of course, later Supreme Court dual sovereignty precedent has wrongly held to the contrary. See Heath v. Alabama, 474 U.S. 82, 93 (1985) (permitting a state prosecution following that of another state).

86 See Mannheimer, supra note 66 (recognizing that common-law precedents are "most closely analogous to successive state-state prosecutions" and criticizing the Gamble Court for its failure to differentiate these different contexts); Amar \& Marcus, supra note 12 at $8 \mathrm{n} .42$ ("English double jeopardy principles... are far more illuminating for state-state dual sovereignty than for federal-state or state-federal dual sovereignty."). 
Absolutely not, as the Constitution's own Supremacy Clause makes clear. ${ }^{87}$ For when there are two sovereigns - just like any two masters - neither can be supreme over the other. ${ }^{88}$

To see this, put aside for a moment the thirteen states at our founding, as that matter has been accounted for above (a corporate merger). Instead, imagine a single, post-Revolutionary War Pennsylvania deciding to adopt a tiered governing structure, ceding some governing authority to each tier. Does each thereby become entitled to its own criminal prosecution of a single offense? Of course not, as the Supreme Court recognized in holding that municipalities are not sovereigns separate from their respective states. ${ }^{89}$ When the Founders chose a federal system of government, they "split the atom of sovereignty," 90 "divid[ing it] between the government of the Union, and those of the states." Splitting is not cloning. Splitting is not duplicating. Splitting is dividing. In creating our constitutional structure, the sovereign states each effectively ceded powers ' $x$ ' and each retained powers ' $1-x$.' Or, even better stated and hearkening again to the words of John Marshall, the sovereign people delegated powers ' $x$ ' to a federal government and powers ' $1-x$ ' to each state government. ${ }^{92}$ The sum of those powers remains just one. After all, as any child might tell us, while we can split a cookie into two parts, it would be ridiculous to assert that we just created a second whole cookie.

Returning to the Court's (imperfect) atomic analogy, when, say, a Uranium235 atom undergoes induced fission, it splits into independent elements, which

87 See U.S. ConsT. art. VI, cl. 2 ("This Constitution, and the Laws of the United States which shall be made in Pursuance thereof . . . shall be the supreme Law of the Land.").

88 Cf. Matthew 6:24 (King James) ("No man can serve two masters: for either he will hate the one, and love the other; or else he will hold to the one, and despise the other."). England, France, and others, then, might jointly form something like the European Union, but such compacts-unlike the American founding-do not make a single sovereign and thus can be unilaterally left, as Brexit demonstrates. See Mark Landler et al., At the Stroke of Brexit, Britain Steps, Guardedly, Into a New Dawn, N.Y. TimeS (Jan. 31, 2020), https://www.nytimes.co $\mathrm{m} / 2020 / 01 / 31 /$ world/europe/brexit-britain-leaves-EU.html.

89 See Waller v. Florida, 397 U.S. 387, 394-95 (1970).

90 U.S. Term Limits, Inc. v. Thornton, 514 U.S. 779, 838 (1995) (Kennedy, J., concurring). See also Alden v. Maine, 527 U.S. 706, 751 (1999) ("By splitting the atom of sovereignty, the Founders established two orders of government, each with its own direct relationship, its own privity, its own set of mutual rights and obligations to the people who sustain it and are governed by it.") (quotation marks and other punctuation omitted); Gamble v. United States, 139 S. Ct. 1960, 1999-2000 n.26 (Gorsuch, J., dissenting) ("The American people split the atom of sovereignty to set two levels of government against each other, not to set both against the people.") (quotation marks and citation omitted).

91 McCulloch v. Maryland, 17 U.S. 316, 410 (1819).

92 See id. at 402-04; Gamble v. United States, 139 S. Ct. 1960, 1999 (2019) (Gorsuch, J., dissenting). 
happen to be isotopes of Krypton and Barium. ${ }^{93}$ Each product is 'lesser' than the 'whole' parent, in the sense that the atomic mass of Uranium has been divided into two portions. But those portions - now constituting the entirely independent elements of Krypton and Barium - have no continuing relationship. The relationship of a constituent American state to the federal government, then, is entirely different, for not only is it continual and unending - the Civil War settled that - but one is ultimately subordinate to the other within that other's limited sphere. According to the Constitution's very terms, "This Constitution, and the Laws of the United States which shall be made in Pursuance thereof... shall be the supreme Law of the Land." 94 That preserves the primacy of the federal government in its limited realm. And the Tenth Amendment, in turn, preserves the primacy of state governments in theirs. ${ }^{95}$ Only in their respective half-realms, so to speak, are these governments each sovereign in our system, and collectively they make but one whole.

Thus, as between the United States and any constituent state, there is only one entire sovereign. ${ }^{96}$ Put another way, over any issue - including any prosecution of a particular criminal "offence" - there is only one sovereign. ${ }^{97}$ Therefore, not even a doctrine of dual sovereignty permits what our governments did to Terance Gamble.

\section{B. The Court's Constitutional Geometry}

Our founding history, then, does not logically permit a federal-state dual sovereignty exception. As it turns out, the Supreme Court has explained double jeopardy in a manner consistent with this logic and history, despite ignoring this precedent in its Gamble opinion. According to the Court in Puerto Rico v. Sanchez

93 See Nuclear Fission, https://en.wikipedia.org/wiki/Nuclear_fission (last visited Oct. 6, 2020); Nuclear Fission, https://www.britannica.com/science/nuclear-fission (last visited Oct. 6, 2020).

94 U.S. CONST. art. VI, cl. 2.

95 U.S. CONST. amend. X ("The powers not delegated to the United States by the Constitution, nor prohibited by it to the States, are reserved to the States respectively, or to the people."). See also Thornton, 514 U.S. at 802 (cautioning that the "Amendment could only 'reserve' that which existed before").

96 See Gamble, 139 S. Ct. at 1990 (Ginsburg, J., dissenting) ("The United States and its constituent States, unlike foreign nations, are 'kindred systems,' 'parts of ONE WHOLE.' The Federalist No. 82, p. 493 (C. Rossiter ed. 1961) (A. Hamilton).”); id. at 1999 (Gorsuch, J., dissenting) ("Alexander Hamilton put the point this way: '[T]he national and State systems are to be regarded' not as different sovereigns foreign to one another but 'as ONE WHOLE.'”).

97 Quoting again from $\mathrm{McC}$ Culloch, "In America, the powers of sovereignty are divided between the government of the Union, and those of the states. They are each sovereign, with respect to the objects committed to it, and neither sovereign, with respect to the objects committed to the other." 17 U.S. at 410 . 
Valle, for double jeopardy purposes, "sovereignty ... does not bear its ordinary meaning." ${ }^{98}$ Instead,

[t]o determine whether two prosecuting authorities are different sovereigns for double jeopardy purposes, this Court asks a narrow, historically focused question. The inquiry does not turn, as the term "sovereignty" sometimes suggests, on the degree to which the second entity is autonomous from the first or sets its own political course. Rather, the issue is only whether the prosecutorial powers of the two jurisdictions have independent origins - or, said conversely, whether those powers derive from the same "ultimate source." 99

And that "single criterion"- "the 'ultimate source' of the power undergirding the respective prosecutions" 100 — can be determined through a bit of constitutional geometry:

The inquiry is...historical, not functional-looking at the deepest wellsprings, not the current exercise, of prosecutorial authority. If two entities derive their power to punish from wholly independent sources (imagine here a pair of parallel lines), then they may bring successive prosecutions. Conversely, if those entities draw their power from the same ultimate source (imagine now two lines emerging from a common point, even if later diverging), then they may not. ${ }^{101}$

Alabama and the United States draw their power from the same ultimate source: our 1788 Constitution. ${ }^{102}$ No matter the precise drafting rules of this constitutional

98 Puerto Rico v. Sanchez Valle, 136 S. Ct. 1863, 1870 (2016).

99 Id. at 1867 . Thus, "[t]he degree to which an entity exercises self-governance... plays no role in the analysis," and "the inquiry (despite its label) does not probe whether a government possesses the usual attributes, or acts in the common manner, of a sovereign entity." Id. at 1870 .

100 Id. at 1871.

101 Id. at 1871 (citation omitted).

102 Again, we hearken to the words of Justice John Marshall. See Gamble v. United States, 139 S. Ct. 1960, 1999 (2019) (Gorsuch, J., dissenting). Despite its Sanchez Valle rule, the Court has never pulled out a pencil and attempted to draw lines. If it did, it would encounter some ambiguity at the very least. For example, when do the 'lines of sovereignty' blink into existence for each of our original thirteen states? Is it with the 1776 Declaration of Independence, with the adoption of each state Constitution, with the 1781 ratification of the Articles of Confederation, or with the 1783 Treaty of Paris?

Fortunately, for our purposes that precise year does not matter. What does matter is that each of the thirteen states was (as described above) originally a separate sovereign, each constituting a distinct parallel line. So, thirteen parallel 'sovereignty lines' begin by 1783 , and they continue until they intersect at a single hub in 1788 with the ratification of our federal Constitution. 
geometry, Alabama cannot have a separate, parallel 'line of sovereignty' when it came into existence in 1817 under the very rules of that 1788 Constitution. ${ }^{103}$ Instead, just as 'the oldest roots of Puerto Rico's power to prosecute lie in federal soil," 104 the oldest roots of the federal government's power to prosecute lie in state soil, a power the people — organized by the states - collectively ceded in 1788 . Thus, both history and precedent dictate that any dual sovereignty exception must be limited to truly foreign sovereigns.

What is more, in his Bartkus dissent, Justice Black famously argued from federalist purpose:

The Court, without denying the almost universal abhorrence of such double prosecutions, nevertheless justifies the practice here in the name of "federalism." This, it seems to me, is a misuse and desecration of the concept. Our Federal Union was conceived and created "to establish Justice" and to "secure the Blessings of Liberty," not to destroy any of the bulwarks on which both freedom and justice depend. We should, therefore, be suspicious of any supposed "requirements" of "federalism" which result in obliterating ancient safeguards. I have been shown nothing in the history of our Union, in the writings of its Founders, or elsewhere, to indicate that individual rights deemed essential by both State and Nation were to be lost through the combined operations of the two governments. Nor has the Court given any sound reason for thinking that the successful operation of our dual system of government depends in the slightest on the power to try people twice for the same act. ${ }^{105}$

So, Gamble is wrong twice (or even thrice) over. As Part III argues, Gamble is wrong as a general matter on account of the limited, humble principles of our constitutional design. And, as we have now developed, Gamble also is wrong as a matter of United States history and federalist structure. ${ }^{106}$

103 It is telling that in Sanchez Valle the Court rather exhaustively describes why neither the states nor the Indian tribes derive their authority from the federal government (see Sanchez Valle, 136 S. Ct. at 1871-72), why municipalities do derive their authority from their respective states (see $i d$.), and why US territories do derive their authority from the United States (see id. at 1873), yet nowhere did the Court attempt to explain how the federal authority could be seen as anything but derived from that of the states or, better yet, their people. How could the "ultimate source"- "all the way back"for federal authority be anything but a concession from the people of the constituent states? Id. at 1875 76.

104 Id. at 1868.

105 Bartkus v. Illinois, 359 U.S. 121, 155-56 (1959) (Black, J., dissenting).

106 Adding garnish, any policy argument for every government requiring a 'bite at the apple' is at its lowest ebb when it comes to the constituent elements of the United States. See id. at 156-57 (Black, J., dissenting). As the then-high court of South Carolina recognized in 1816, if the double jeopardy limitation "prevails among nations who are strangers to each other, could 


\section{CONCLUSION}

In 1959, Justice Black bemoaned that, based upon decades of Supreme Court precedent, "[p]eople have apparently become more accustomed to double trials ... just as they might, in time, adjust themselves to all other violations of the Bill of Rights should they be sanctioned by this Court." 107 Alas. We now have lived through six decades more of such precedent, culminating most recently in the Court's 2019 Gamble decision. Like Justice Black before us, we fear "the victims of such double prosecutions will most often be the poor and the weak in our society," and "those who differ, who do not conform." "The That has ever been the case.

Yet more subtly or indirectly, when our governing systems fail to live up to basic norms of criminal justice we are all — each and every one of us - among its victims. Such failures diminish us and can discourage us. But despite Gamble's dual sovereignty exception attracting seven votes, and despite the hundreds of years of (meandering) precedent in greater or lesser support of the doctrine, we remain hopeful that its mistakes will be rarely invoked, ${ }^{109}$ and even corrected in time. As Leonard Cohen reminds, "There is a crack in everything; that's how the light gets in. ${ }^{~} 110$ We hope we have called attention to just such an opening. ${ }^{111}$

it fail to be exercised with us who are so intimately bound by political ties?" State v. Antonio, 2 Tread. 776, 781 (S.C. 1816).

107 Bartkus, 359 U.S. at 162-63 (Black, J., dissenting).

108 Id. at 163.

109 States and the federal government can, of course-and sometimes do-adopt a policy generally refusing to bring duplicative prosecutions. See e.g., Gamble v. United States, 139 S. Ct. 1960, 1995 (2019) (Ginsburg, J., dissenting) (explaining the federal government's so-called "Petite policy"); Thompson v. United States, 444 U.S. 248, 248-51 (1980) (same). And any individual prosecutor could, even absent a fixed policy, do the same. Of course, prosecutorial promises not to play with matches are not a full or satisfying substitute for the constitutional firewall of the Double Jeopardy Clause, rightly interpreted.

110 Leonard Cohen, Anthem, on The Future (Columbia Records 1992).

111 Like countless others, we also draw inspiration from the sense that although our collective 'moral arc' is a long one, it "bends toward justice." John Craig, Wesleyan Baccalaureate Is Delivered by Dr. King, HARTFORD COURANT, June 8, 1964, at 4 (quoting Martin Luther King Jr.). Dr. King was citing what had become a concise variant of Theodore Parker's words:

I do not pretend to understand the moral universe, the arc is a long one, my eye reaches but little ways. I cannot calculate the curve and complete the figure by the experience of sight; I can divine it by conscience. [And] from what I see[,] I am sure it bends toward justice.

TheOdORE PARKer, TEN SERMONS OF ReLigion 84-85 (1853). 